\title{
Long-term Follow-up of Clofazimine (Lamprene) in the Management of Reactive Phases of Leprosy
}

\author{
A. B. A. KARAT \\ St. Catherine's Hospital, Birkenhead, England
}

\begin{abstract}
Observations in 120 leprosy patients with reaction treated with Lamprene for periods ranging from 3 mon ths to 5 years are presented. Lamprene was found to be an effective therapy for ENL, acute neuritis, eye complications associated with reaction, epistaxis, haemoptysis and nasal discharge due to leprous rhinitis. No adverse effects were noticed in 3 women who were on continuous treatment with Lamprene immediately prior to their becoming pregnant, throughout pregnancy and puerperium. Except for hyperpigmentation of the child, no other deleterious effect on the foetus was noted. Two patients developed "granulomatous enteritis" while on Lamprene. Bacterial clearance as judged by fall in BI was comparable to that seen in patien ts on dapsone $100 \mathrm{mg}$ daily.

After 6 months of continuous treatment, no recurrence of ENL was seen in any of the patients. There was significant improvement in motor and sensory functions in patients with acute neuritis in all types of leprosy.
\end{abstract}

A large number of short-term studies since the original reports of the efficacy of Lamprene in lepromatous leprosy have confirmed both specific bacteriostatic effect on Myco. leprae as well as an anti-inflammatory effect in suppressing clinical manifestations of reactive phases in leprosy (Browne and Hogerzeil (1962a, 1962b; Browne 1965; Hastings and Trautman 1968; Karat et al., 1970; 1971). We have had the opportunity to treat 120 leprosy patients with complicating reactive phase over a 5 year period of whom 50 patients were followed up for 5 years. This paper summarizes our findings.

\section{Material and Method}

Two hundred and forty leprosy patients with 1 or more complications of reactive phases of leprosy were treated with Lamprene over a 5 year period and entered a controlled clinical trial. All of them had a detailed clinical examination, bacteriological and histological assessments, detailed assessment of neurological and ophthalmic functions. One hundred and twenty of these patients were on Lamprene $100 \mathrm{mg}$ t.d.s. for 12 weeks followed by a maintenance dose of Lamprene $100 \mathrm{mg}$ daily. The other 120 patients were on dapsone $50 \mathrm{mg}$ daily along with Prednisolone $10 \mathrm{mg}$ t.d.s. for 12 weeks and thereafter a maintenance therapy of dapsone $50 \mathrm{mg}$ daily. In this paper only the patients on Lamprene are described. 


\section{Findings}

The distribution of patients according to classification of leprosy and complication(s) of reaction is shown in Table 1 .

TABLE 1

Distribution of patients according to classification of leprosy and complication of reaction

\begin{tabular}{|c|c|c|c|c|c|}
\hline Complication $\quad$ Classification & $\mathrm{TT}$ & BT & BL & LL & Total \\
\hline Acute neuritis & 6 & 10 & 30 & 34 & 80 \\
\hline ENL (Grade III/IV) & - & - & 24 & 60 & 84 \\
\hline Iritis/Iridocyclitis/Scleritis & - & - & 6 & 10 & 16 \\
\hline Epistaxis/stuffy nose & - & - & 10 & 20 & 30 \\
\hline Hoarseness of voice & - & - & - & 10 & 10 \\
\hline
\end{tabular}

\section{Erythema nodosum leprosum (ENL)}

Only patients who had 3 or more episodes of severe ENL were included in the study. Of the 84 patients in this category, in 80 patients $(95 \%)$, the ENL was controlled in 4 to 8 weeks. The remaining 4 patients while showing clinical improvement continued to have manifestations of less severe ENL and needed additional therapy in the form of Prednisolone $5 \mathrm{mg}$ t.d.s. for 4 to 12 weeks to adequately control the reaction.

Recurrence of milder ENL while on maintenance therapy with Lamprene $100 \mathrm{mg}$ daily was noted in $8(10 \%)$ of the 80 patients in whom the reaction had come under control on Lamprene $300 \mathrm{mg}$ daily for 12 weeks. No recurrence of ENL was noted after 6 months in any of the patients, 50 of whom were followed up for 5 years.

All the patients showed a weight gain of 5 to $10 \mathrm{~kg}$ during the follow-up period.

There was significant rise in haemoglobin and haematocrit values while on Lamprene without supplementation with haematinics. The reversal of albuminglobin ratio in the serum tended to correct itself with rising albumin and falling globulin. The sedimentation rate also showed a significant reduction.

\section{Acute neuritis}

(a) Tuberculoid Leprosy. Six patients with acute mononeuritis of less than a week's duration were studied. There was complete relief of pain in 4 weeks in all the patients. Motor and sensory recovery was first noted between 2 to 4 weeks from commencement of treatment and continued to improve for 12 months. No significant improvement was noticed after 12 months during follow-up period which ranged from 6 months to 4 years. In none of the patients was a recurrence of neuritis seen after 12 months of treatment. In 2 patients there was no change.

Neurological status of TT patients on Lamprene (6 patients)

\begin{tabular}{lcccccccc}
\hline $\begin{array}{l}\text { No. of } \\
\text { patients }\end{array}$ & $\begin{array}{r}\text { Symptoms } \\
\text { and signs }\end{array}$ & $\begin{array}{c}\text { Pain } \\
\text { relief }\end{array}$ & \multicolumn{2}{c}{ Motor recovery } & \multicolumn{2}{c}{ Sensory recovery } & $\begin{array}{c}\text { No change in } \\
\text { neurological } \\
\text { function }\end{array}$ \\
\hline & 6 & 3 & 1 & 3 & 1 & 2 \\
\hline
\end{tabular}


(b) Borderline/Tuberculoid (BT) Leprosy (10 patients). The response in this group was similar to TT.

\begin{tabular}{l}
$\begin{array}{l}\text { No. of } \\
\text { patients }\end{array}$ \\
\hline 9
\end{tabular}

(c) BL and LL (30 and 34). Patients showed comparable response. In none of the patients was there complete recovery of motor or sensory functions.

\begin{tabular}{|c|c|c|c|c|c|c|c|}
\hline \multirow{2}{*}{$\begin{array}{l}\text { No. of } \\
\text { patients }\end{array}$} & \multirow{2}{*}{$\begin{array}{r}\begin{array}{r}\text { Symptoms } \\
\text { and signs }\end{array} \\
\end{array}$} & \multirow{2}{*}{$\begin{array}{l}\text { Pain } \\
\text { relief }\end{array}$} & \multicolumn{2}{|c|}{ Motor recovery } & \multicolumn{2}{|c|}{ Sensory recovery } & \multirow{2}{*}{$\begin{array}{l}\text { No change in } \\
\text { neurological } \\
\text { function }\end{array}$} \\
\hline & & & Partial & Complete & Partial & Complete & \\
\hline & & 60 & 30 & 0 & 40 & 0 & 24 \\
\hline
\end{tabular}

There was significant improvement in neurological function in well over half the patients. Again there was no recurrence after 1 year of continuous therapy.

\section{Eyes (Iritis/Iridocyclitis/Scleritis)}

Ophthalmological complications associated with ENL reaction were seen in 16 patients. Apart from mydriatics no other local therapy was given. All the patients found relief of symptoms in 4 weeks and marked improvement at the end of 12 weeks. They continued to improve for 18 months. Visual acuity improved by at least 1 line on Snellen's chart in all the patients.

\section{Epistaxis-Nasal Discharge- "Blocking”" of the nose}

Ten patients with BL leprosy and 20 patients with LL leprosy had epistaxis, profuse nasal catarrh and difficulty in breathing because of blocking of the nose. The epistaxis cleared when the reaction came under control. Nasal discharge and blocking of the nose improved gradually over a 6 month period. Nasal discharge was noticed to have a brownish discolouration between 12 and 16 weeks of commencement of treatment.

\section{Hoarseness of voice and haemoptysis}

This was seen in 10 lepromatous leprosy patients. The haemoptysis cleared in 8 weeks while there was gradual improvement in hoarseness of voice over a period of 18 months.

\section{Pregnancy and Lamprene}

Three women who had been on Lamprene for management of severe, chronic ENL became pregnant at 3 months, 9 months and a year after initiation of therapy with Lamprene and continued with Lamprene $100 \mathrm{mg}$ daily throughout 
pregnancy and puereperium. No untoward effects were observed either in the mother or the foetus except for somewhat darker colour of the skin of the offspring, more than can be accounted for by the ethnic background. The pigmentation gradually faded away over a one year period.

\section{Clearance of Myco. leprae}

Fifty patients with BL and LL leprosy were available for follow-up over a 5 year period. Forty of them became skin smear negative between 1 and 5 years from initiation of treatment. Average drop in Bacterial Index (Ridley's Scale) was $1+$ per year of treatment, comparable to that seen in patients on dapsone $100 \mathrm{mg}$ daily.

\section{Side-effects}

The occurrence of red-brown pigmentation was seen in all the patients within 12 weeks of initiation of treatment. Dry, scaly, ichthyotic changes in the skin were seen in the extensor surfaces of the upper and lower extremities in over $75 \%$ of patients. This improved with immersion in water for $15 \mathrm{~min}$ followed by application of a thin layer of vegetable oil or vaseline. In a number of patients partial regrowth of eyebrows was a welcome effect.

Gastrointestinal tolerance was good when daily dose did not exceed $300 \mathrm{mg}$. Among the 120 patients 2 patients developed recurrent, colicky abdominal pain after 6 months and 18 months of regular intake of Lamprene. Barium meal studies showed narrowing of the terminal ileum, and dilatation of proximal loop of ileum. There was no change in the absorptive functions of the small intestine. At laparotomy, about 6 in of terminal ileum appeared thickened and oedematous. There were a few enlarged mesenteric lymph nodes. Biopsy of the glands as well as terminal ileum showed non-specific granuloma characterized by the presence of foreign body giant cells and lymphocytes. The sections also showed crystals of Lamprene in the granulomata. No AFB were grown on culture. Lamprene was withdrawn from these patients and the symptoms cleared up in 8 to 10 weeks.

The sweat, urine, tears, nasal discharge, semen and breast milk developed varying degrees of brownish discolouration.

By slit-lamp microscopy one could demonstrate crystals of clofazimine in the iris, conjunctiva, sclera and cornea about 6 months after initiation of therapy. In patients who had more than 6 months of continuous therapy about $25 \%$ of patients developed asymptomatic bluish discolouration of the lens. These changes in the eye were reversible and cleared up over a period of 6 to 12 months after cessation of therapy with Lamprene.

\section{Acknowledyements}

I am grateful to Ciba-Geigy, Basel, for making this study possible. It is a pleasure to acknowledge my indebtedness to Mrs S. Karat for help with biopsies, neurological assessments including EMG studies, to the many house physicians who have helped with the day to day care, the laboratory and physiotherapy staff for their help. 


\section{References}

Browne, S. G. (1965). Lepr. Rev. 36, 9.

Browne, S. G. and Hogerzeil, L. M. (1962a). Lepr. Rev. 33, 6.

Browne, S. G. and Hogerzeil, L. M. (1962b). Lepr. Rev. 33, 182.

Hastings, R. C. and Trautman, J. R. (1968). Lepr. Rev. 39, 3.

Karat, A. B. A., Aubn Jeevaratnam, Karat, S. and Rao. P. S. S. (1970). Br. med. J. 1, 198.

Karat, A. B. A., Aubn Jeevaratnam, Karat, S. and Rao, P. S. S. (1971). Br. med. J. 4, 514. 